\begin{tabular}{|c|c|c|c|}
\hline \multirow{2}{*}{$\begin{array}{r}\text { Case Reports in } \\
\text { Gastroenterology }\end{array}$} & \multicolumn{2}{|c|}{ Case Rep Gastroenterol 2015;9:246-252 } & \multirow[b]{2}{*}{$\begin{array}{l}\text { Karger } \\
\text { Open'access }\end{array}$} \\
\hline & $\begin{array}{l}\text { DOI: 10.1159/000437294 } \\
\text { Published onlIne: July 2I, } 2015\end{array}$ & $\begin{array}{l}\text { (C) } 2015 \text { S. Karger AG, Basel } \\
\text { 1662-0631/15/0092-0246 } \$ 39.50 / 0 \\
\text { www.karger.com/crg }\end{array}$ & \\
\hline & $\begin{array}{l}\text { This is an Open Access article licen } \\
\text { NonCommercial } 3.0 \text { Unported lice } \\
\text { the online version of the article onl }\end{array}$ & $\begin{array}{l}\text { ns of the Creative Commons Attribution } \\
\text { ww.karger.com/OA-license), applicable } \\
\text { nitted for non-commercial purposes onl }\end{array}$ & \\
\hline
\end{tabular}

\title{
T-Cell Lymphomas Presenting as Colon Ulcers and Eosinophilia
}

\author{
Ping-Hsiu Wu ${ }^{a} \quad$ Kuang-En Chu ${ }^{a} \quad$ Yu-Min Lin ${ }^{a}$ Shu-Han Huang ${ }^{b}$ Chin- \\ $\mathrm{Chu} \mathrm{Wu}^{\mathrm{c}}$ \\ Departments of ${ }^{a}$ Internal Medicine, Division of Hepatology and Gastroenterology, \\ ${ }^{b}$ Pathology and ${ }^{c}$ Radiology and Images Studies, Shin Kong Wu Ho-Su Memorial Hospital, \\ Taipei, Taiwan, ROC
}

\section{Key Words}

T-cell lymphoma $\cdot$ Colitis $\cdot$ Eosinophilia $\cdot$ Crohn's disease

\begin{abstract}
Primary gastrointestinal T-cell lymphoma is an uncommon entity and primary colon T-cell lymphoma is even rarer. The majority of enteropathy-associated T-cell lymphomas present predominantly as ulcers or strictures in the endoscopic examinations, while primary B-cell lymphomas commonly present as exophytic lesions. Ulcerative colon T-cell lymphoma may mimic Crohn's disease (CD), which is a chronic inflammatory disease of the intestines with ulcer and fistula formations difficult for clinicians to diagnose based on endoscopic observations alone. Like $C D$, T-cell lymphoma may be characterized by the presence of multiple skipped ulcers distributed from the terminal ileum to the descending colon. Furthermore, it is difficult to diagnose this unusual lymphoma by a single endoscopic biopsy. Typically, the histological composition of T-cell lymphoma is made of medium to large atypical cells located in the base of the ulcer with extension to the muscle layer and the adjacent mucosa. However, it is common that biopsy specimens show only mixed inflammatory changes where the lymphoma cells are hard to be identified. The differential diagnosis of malignant lymphoma must be considered when clinically diagnosed $C D$ is refractory to the medical treatment or when its clinical behavior becomes aggressive. The current study presents a rare case of primary colon T-cell lymphoma in a 56-year-old male with marked recent weight loss, watery diarrhea and bilateral neck lymphadenopathy, who received a laboratory checkup and endoscopic workup for colon biopsy. The initial pathological report was consistent with mucosal inflammation and benign colon ulcers. Interestingly, the blood test showed a prominent eosinophilia. A biopsy of the enlarged neck lymph nodes done approximately 1 month after the colon biopsy unexpectedly showed T-cell lymphoma, which led to a review of the
\end{abstract}


Wu et al.: T-Cell Lymphomas Presenting as Colon Ulcers and Eosinophilia

initial colonic biopsy specimens. Additional immunohistochemical stains were used accordingly, which showed positive results for CD3, CD45RO and LCA antibodies confirming the diagnosis of lymphoma. The endoscopic diagnosis of ulcerative colon T-cell lymphoma is frequently confused with inflammatory conditions of the large bowel such as $C D$, and tuberculosis colitis. Our study aims to emphasize the difficulty in differentiating this ulcerative form of colon T-cell lymphoma from the inflammatory bowel diseases and the importance of its differential diagnosis due to the much more aggressive clinical behavior of the T-cell lymphoma.

(C) 2015 S. Karger AG, Basel

\section{Introduction}

Lymphoma of the colon is a rare disease which accounts for $6-12 \%$ of gastrointestinal lymphomas. When lymphoma involves the gastrointestinal tract, the stomach and small intestine are most commonly affected, whereas the colon and rectum are rarely involved [1]. Symptoms are mainly nonspecific and include diarrhea, unexplained weight loss, abdominal pain and bowel habit change. Radiological images of T-cell lymphomas may show mucosal ulcerations and nodularities very similar to Crohn's disease (CD) and mucosa-associated lymphoid tissue lymphomas (MALTomas) [2]. Colonoscopic pictures of lymphoma may present as a diffuse or segmental ulceration mimicking CD or tuberculosis [3]. An interesting case of T-cell lymphoma presenting unusual colonoscopic findings is presented in this report. Our patient presented to the emergency room with diarrhea, abdominal pain, progressive weight loss, fever and general malaise. The initial diagnosis after colonoscopic biopsy was unspecific colitis and colon ulcers. Empiric treatment with oral mesalazine was instituted accordingly. However, the patient deteriorated rapidly in spite of the treatment, and he was sent back to the emergency room 1 month later with a markedly deteriorated condition and multiple enlarged lymph nodes in the neck. The pathological result of the biopsy taken from the neck revealed malignant T-cell lymphoma, which led to a review of the colon biopsy performed previously. The diagnosis of colon T-cell lymphoma was ultimately established after performing some special immunohistochemical stains, such as CD3, CD45RO, LCA and CD 20 antibodies. As illustrated by this case, the difficulty of a prompt diagnosis of colon Tcell lymphoma has to be emphasized as well as the need for an early diagnosis and a timely treatment of this aggressive clinical entity.

\section{Case Report}

A 56-year-old man with no remarkable previous medical history presented to the outpatient clinic with profuse diarrhea, abdominal fullness, nausea, retching, and poor appetite. Over the past 3 months, he lost weight, about $8 \mathrm{~kg}$ (his weight was $69 \mathrm{~kg}$ before the symptoms started), and experienced intermittent low-grade fevers, which were more noticeable in the afternoon and during the night. The physical examination showed a slightly dehydrated patient; there were no palpable lymph nodes in the neck, axillae or inguinal areas. The abdomen was distended and slightly tender on palpation; the bowel sounds were normoactive. The leukocyte count was $10,100 / \mu \mathrm{l}$, with a prominent eosinophilia $(56.3 \%)$. The hemoglobin, platelets and biochemistry tests were within normal limits. Partial parenteral nutrition was instituted as soon as the patient was hospitalized. A colonoscopy showed multiple ulcers with peripheral edema from the cecum to the sigmoid colon, while the rectum was relatively spared (fig. 1). The terminal ileum was free of active lesions. Biopsy for pathology 
Wu et al.: T-Cell Lymphomas Presenting as Colon Ulcers and Eosinophilia

and tuberculosis was done, which initially showed unspecific ulcers. The patient received oral mesalazine (2.4 g daily), and he was dismissed in a relatively stable condition. One month later, the patient was sent back to the emergency room with a deteriorated condition and exacerbated diarrhea, in spite of the oral mesalazine. Several enlarged and palpable lymph nodes appeared in the neck. A computed tomography showed multiple enlarged lymph nodes throughout the body, including the neck, the bilateral supraclavicular space, axillary regions, mediastinum, para-aortic, splenic hilum, and inguinal regions (fig. 2). A biopsy of the lymph nodes taken from the neck was performed and the pathology showed malignant T-cell lymphoma. The specimen from the colonoscopy biopsy was reviewed again accordingly, and further immunohistochemical studies showed prominent atypical lymphoid cells with positive reactivity for CD3, CD45RO and LCA antibodies, and negative reactivity for CD20 antibodies. Focal histiocytes reactive for CD68 antibody infiltration in the lamina propria were also seen (fig. 3). Based on the immunohistochemical stains, malignant lymphoma (T-cell type) of the colon was ultimately diagnosed. The patient was referred to the oncology department, and chemotherapy was started shortly after the final diagnosis was obtained.

\section{Discussion}

Gastrointestinal lymphomas are a group of aggressive malignancies which are clinically rare and hard to be diagnosed. The incidence of T-cell lymphoma is $0.5-1$ per million per year [4], and most of the cases are diagnosed in an advanced stage. The 1- and 5-year survival rates are 31-39\% and 8-20\%, respectively [5]. Most gastrointestinal lymphomas have a B-cell origin, while T-cell lymphomas are extremely rare in the gastrointestinal tract [6]. Some cases of T-cell lymphomas associated with peripheral eosinophilia have been reported previously. It is noteworthy that these particular cases were found to be refractory to chemotherapy and may therefore carry a poor outcome [7]. Eosinophilia is typically associated with parasitic infections or allergic disorders, and may be involved in eosinophilic infiltrates in various tissues and organs such as the lungs, heart, nervous system, and gastrointestinal tract. In addition to the parasitic infections and allergic disorders, some diseases such as lymphoproliferative neoplasms, particularly non-Hodgkin T-cell lymphoma and Hodgkin lymphoma, may be accompanied with eosinophilia as well. The reason is unclear, but it may be caused by lymphokines [8]. An overproduction of interleukin-3 and granulocyte macrophage colony-stimulating factor by the lymphoma cells contribute to maturation and the proliferation of eosinophil precursors along with other lineages. The presence of eosinophilia should alert the potential existence of a significant underlying disease. The differential diagnosis of colon ulcers must include tuberculosis, CD and lymphoma, which are difficult to be differentiated based solely on the endoscopic findings. This is particularly challenging in Taiwan since the incidence of tuberculosis and CD has been increasing in the past 10 years [9]. Clinically, T-cell lymphoma has an aggressive course with a poor prognosis, whereas CD may be relapsing over the years, alternating with symptom-free periods. Due to the absence of specific symptoms, the more aggressive T-cell lymphoma is often misdiagnosed as CD, and treated with immunosuppressive agents accordingly. The colorectal T-cell lymphoma may appear either as a diffuse presentation $(58.8 \%)$ or as an ulcerative morphology $(80.0 \%)$ $[10,11]$.

In summary, a prompt diagnosis of gastrointestinal T-cell lymphoma may be challenging. The diagnosis is often made from surgically resected specimens or colonoscopic biopsies. Improvements in pathological and immunohistochemical stains have also improved the diagnostic rate in recent years. Due to the difficult diagnosis, as illustrated in this case report, 
Wu et al.: T-Cell Lymphomas Presenting as Colon Ulcers and Eosinophilia

the possibility of lymphoma should always be kept in mind in patients with colonic ulcerative conditions. Close endoscopic surveillance and other image modalities, such as computed tomography scans, and laboratory findings, such as unexplained eosinophilia in the blood, may also help to obtain a diagnosis and start an appropriate treatment.

\section{Disclosure Statement}

The authors declare that there are no conflicts of interests.

\section{References}

1 Wychulis AR, Beahrs OH, WooIner LB: Malignant lymphoma of the colon. Arch Surg 1966;93:215-225.

-2 Lee HJ, Han JK, Kim TK: Primary colorectal lymphoma: spectrum of imaging findings with pathologic correlation. Eur Radiol 2002;12:2242-2249.

-3 Ghimire P, Wu G-Y, Zhu L: Primary gastrointestinal lymphoma. World J Gastroenterol 2011;17:697-707.

4 Delabie J, Holte H, Vose JM: Enteropathy-associated T-cell lymphoma: clinical and histological findings from the international peripheral T-cell lymphoma project. Blood 2011;118:148-155.

5 Van de Water JM, Cillessen SA, Visser OJ, Verbeek WH, Meijer CJ, Mulder CJ: Enteropathy associated T-cell lymphoma and its precursor lesions. Best Pract Res Clin Gastroenterol 2010;24:43-56.

6 Isaacson PG: Gastrointestinal lymphoma. Hum Pathol 1994;10:1020-1029.

-7 Yap E, Wan Jamaluddin WF: NK/T cell lymphoma associated with peripheral eosinophilia. Malays J Pathol 2014;36:201-205.

-8 Campo E, Swerdlow SH, Harris NL: The 2008 WHO classification of lymphoid neoplasms and beyond: evolving concepts and practical applications. Blood 2011;117:5019-5032.

-9 Wei SC, Lin MH, Tung CC: A nationwide population-based study of the inflammatory bowel diseases between 1998 and 2008 in Taiwan. BMC Gastroenterol 2013;13:166.

10 Kim YH, Lee JH, Yang SK: Primary colon lymphoma in Korea: a KASID (Korean Association for the Study of Intestinal Diseases) Study. Dig Dis Sci 2005;50:2243-2247.

-11 Hirakawa K, Fuchigami T, Nakamura S: Primary gastrointestinal T-cell lymphoma resembling multiple lymphomatous polyposis. Gastroenterology 1996;111:778-782. 


\begin{tabular}{|c|c|c|}
\hline \multirow{3}{*}{$\begin{array}{r}\text { Case Reports in } \\
\text { Gastroenterology }\end{array}$} & \multirow{2}{*}{\multicolumn{2}{|c|}{ Case Rep Gastroenterol 2015;9:246-252 }} \\
\hline & & \\
\hline & DOI: 10.1159/000437294 & $\begin{array}{l}\text { (c) } 2015 \text { S. Karger AG, Basel } \\
\text { www.karger.com/crg }\end{array}$ \\
\hline
\end{tabular}
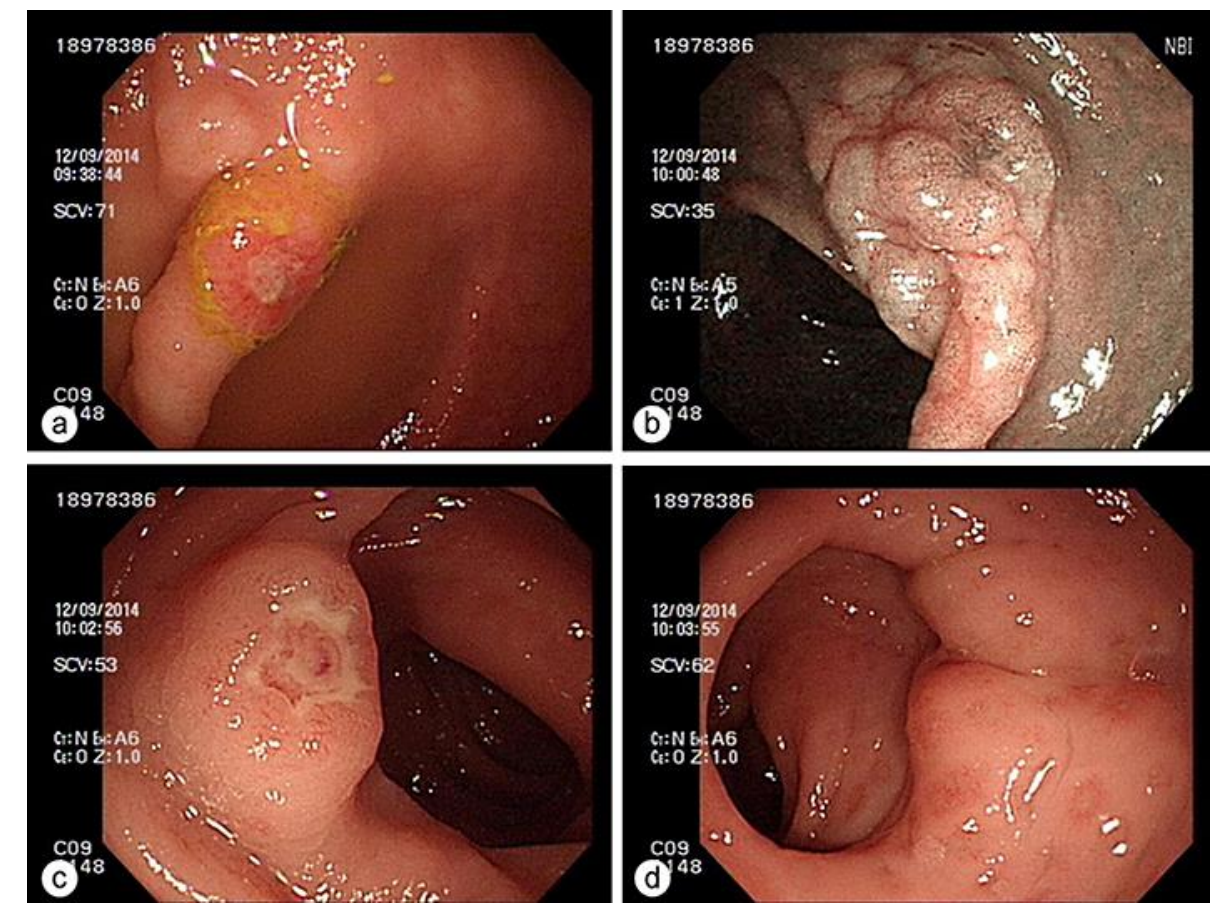

Fig. 1. A colonoscopic study revealed multiple, deep, and geographic ulcers coated with inflammatory exudate and surrounded by edematous margins throughout the entire colon. 


\begin{tabular}{|c|c|c|}
\hline \multirow{3}{*}{$\begin{array}{r}\text { Case Reports in } \\
\text { Gastroenterology }\end{array}$} & \multirow{2}{*}{\multicolumn{2}{|c|}{ Case Rep Gastroenterol 2015;9:246-252 }} \\
\hline & & \\
\hline & DOI: 10.1159/000437294 & $\begin{array}{l}\text { (c) } 2015 \text { S. Karger AG, Basel } \\
\text { www.karger.com/crg }\end{array}$ \\
\hline
\end{tabular}
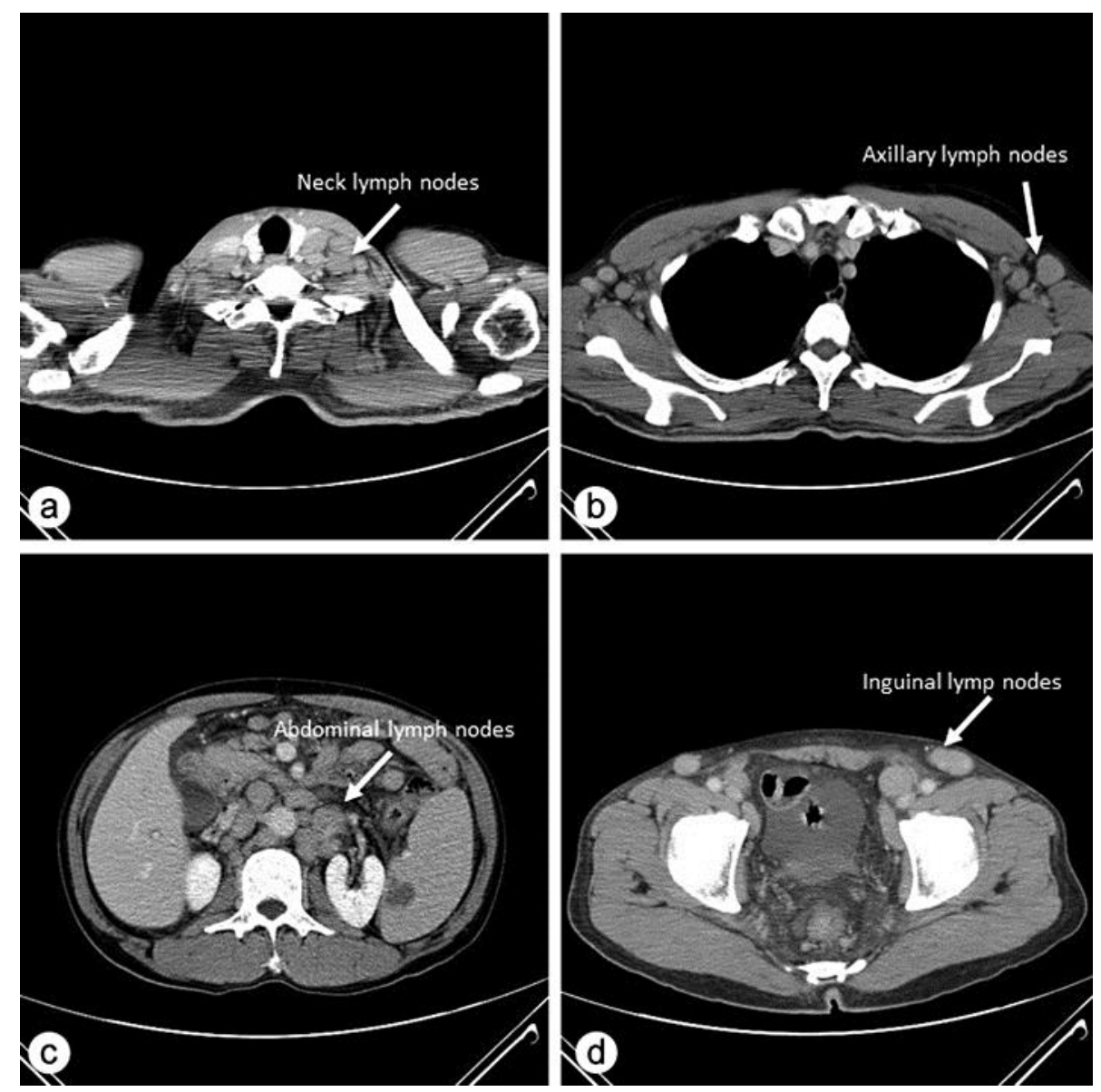

Fig. 2. A computed tomography showed multiple enlarged lymph nodes throughout the body, including the neck (a), axillary regions (b), abdomen (c), and inguinal regions (d). 


\begin{tabular}{|c|c|c|}
\hline \multirow{3}{*}{$\begin{array}{l}\text { Case Reports in } \\
\text { Gastroenterology }\end{array}$} & \multirow{2}{*}{\multicolumn{2}{|c|}{ Case Rep Gastroenterol 2015;9:246-252 }} \\
\hline & & \\
\hline & DOI: $10.1159 / 000437294$ & $\begin{array}{l}\text { (c) } 2015 \text { S. Karger AG, Basel } \\
\text { www.karger.com/crg }\end{array}$ \\
\hline
\end{tabular}

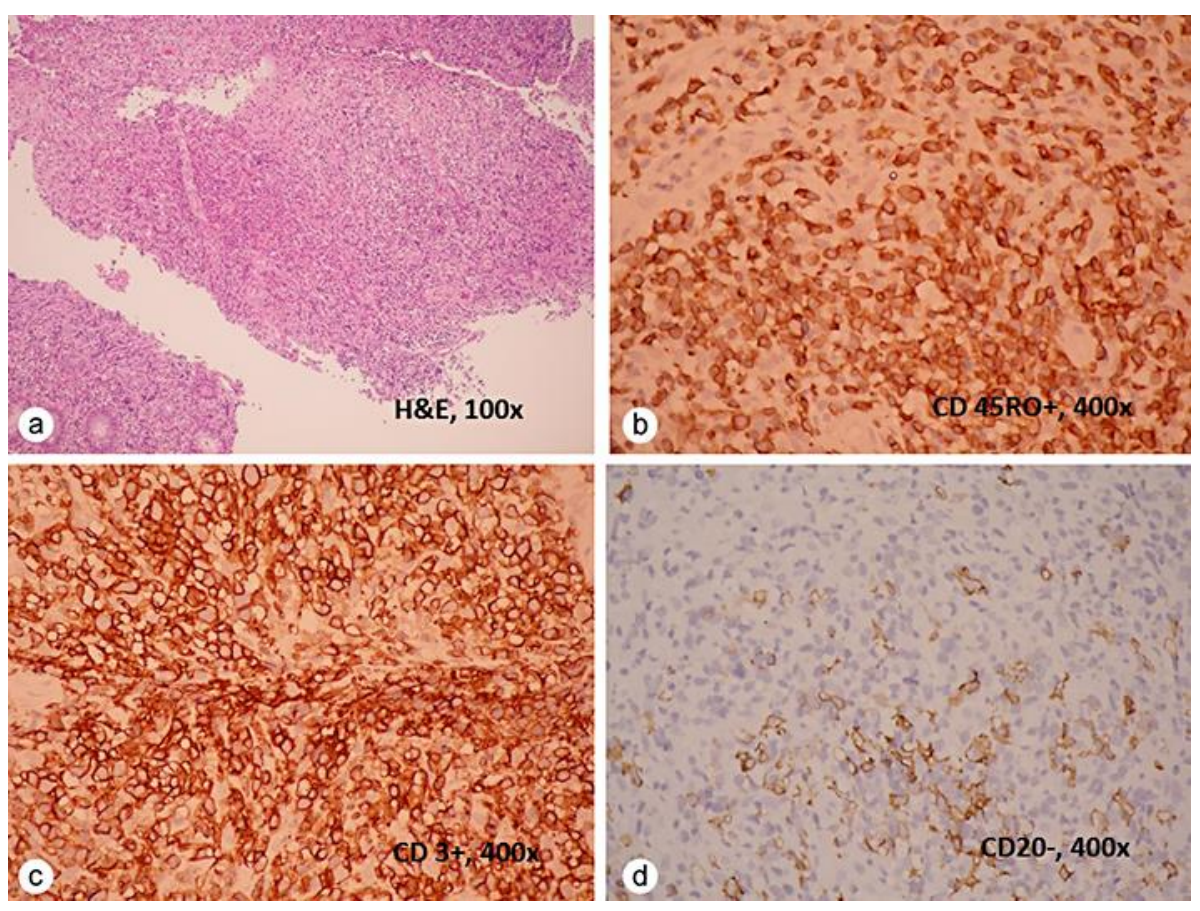

Fig. 3. Histological picture of the colonic specimens obtained by endoscopic biopsy showing dense inflammatory cells infiltrated in the lamina propria and intraepithelial infiltration of atypical lymphocytes. a Hematoxylin and eosin stain $(\times 100$; immunohistochemical studies $)$ showed prominent atypical lymphoid cells with a positive reactivity for CD45RO (b) $(\times 400)$ and CD3 (c) $(\times 400)$ antibodies and a negative reactivity for $\mathrm{CD} 20$ (d) $(\times 400)$ antibodies. 